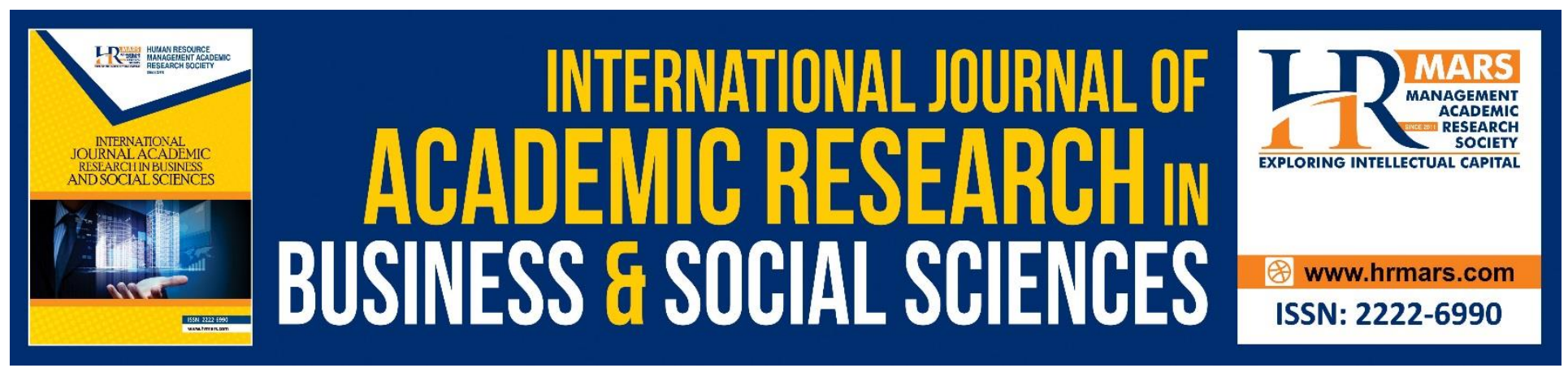

\title{
Effects of Current Account Deficit on the Value of Indian Rupee
}

\author{
Sandeep Patalay
}

To Link this Article: http://dx.doi.org/10.6007/IJARBSS/v8-i10/5272

DOI: $10.6007 /$ IJARBSS/v8-i10/5272

Received: 19 Sept 2018, Revised: 21 Oct 2018, Accepted: 26 Oct 2018

Published Online: 03 Nov 2018

In-Text Citation: (Patalay, 2018)

To Cite this Article: Patalay, S. (2018). Effects of Current Account Deficit on the Value of Indian Rupee. International Journal of Academic Research in Business and Social Sciences, 8(10), 1135-1144.

Copyright: @ 2018 The Author(s)

Published by Human Resource Management Academic Research Society (www.hrmars.com)

This article is published under the Creative Commons Attribution (CC BY 4.0) license. Anyone may reproduce, distribute, translate and create derivative works of this article (for both commercial and non-commercial purposes), subject to full attribution to the original publication and authors. The full terms of this license may be seen at: $\underline{\text { http://creativecommons.org/licences/by/4.0/legalcode }}$

$$
\text { Vol. 8, No. 10, 2018, Pg. } 1135 \text { - } 1144
$$

Full Terms \& Conditions of access and use can be found at http://hrmars.com/index.php/pages/detail/publication-ethics 


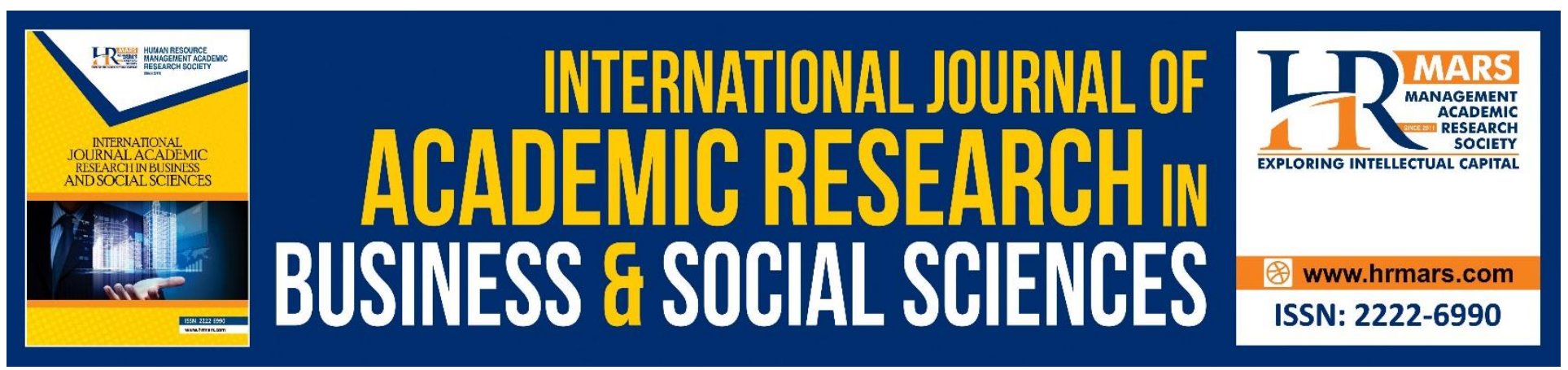

\title{
Effects of Current Account Deficit on the Value of Indian Rupee
}

\author{
Sandeep Patalay \\ Research Scholar, Dept. of Management Studies, VFSTR (Deemed to be \\ University), Vadlamudi, Guntur, Andhra Pradesh 522213, India \\ Email: sandeep.patalay@gmail.com
}

\begin{abstract}
In economics, a country's current account is one of the two components of its balance of payments, the other being the capital account (sometimes called the financial account). The current account consists of the balance of trade, net primary income or factor income (earnings on foreign investments minus payments made to foreign investors) and net cash transfers that have taken place over a given period of time. A country's balance of trade is the net or difference between the country's exports of goods and services and its imports of goods and services, ignoring all financial transfers, investments and other components, over a given period of time. A country is said to have a trade surplus if its exports exceed its imports and a trade deficit if its imports exceed its exports. Positive net sales abroad generally contribute to a current account surplus; negative net sales abroad generally contribute to a current account deficit (CAD). In any country's economy the Current Account Deficit (CAD) is the one of the key indicators of Macro Economic stability. In this paper we analyse India's CAD situation and how changes in the CAD affects the rupee stability. We build a model that explains the effects of CAD on the value of the domestic currency (Rupee). Indian economy and currency (In-terms of \$) is taken up as a case study for building the model and discussed for the effects and conclusions based on hypothetical data. Since most of the payments done by India are in US Dollars, the model takes in to account the Supply and Demand functions for the Dollar and its effect on the local currency fluctuations. The model also explains how the currency fluctuations in-turn contributes to widen the CAD and finally leading to currency crisis.
\end{abstract}

\section{Introduction}

CAD is one of the key macro-economic indicators of any economy; the effects of CAD are far reaching on many economic parameters and have a direct effect of the stability of the currency of any country. The CAD for any country depends on the supply \& demand of global basket of currencies to make payments of their imports. The US Dollar is by far the most dominant reserve currency for many countries. In this paper, we build a model initially to reflect the supply and demand functions of the 
Dollar with respect to Indian Rupee and derive the equations for the equilibrium point. Once the equations for the equilibrium point are derived, we use them for modelling the CAD fluctuations and derive the new equilibrium point due to new demand curve.

For simplicity, we consider the model to be linear and model the functions based on linear algebraic equations. We derive the equilibrium point of Price(P0) and Quantity(Q0) under general equilibrium, later we introduce the changes in the CAD to seek new Price (P1) and Quantity(Q1).

In the results section, we use the model developed in the earlier sections to make inferences on the possible effects on the currency fluctuations and economy in general. The CAD deficit has a deadly effect on the currency valuation and leads to a vicious cycle where FDI flies out of the country and domestic currency loses value very rapidly leading to domestic hyperinflation.

\section{Literature Review}

The literature in the recent past related to the effects of CAD on the currency fluctuations has been reviewed and older literature has been considered where the theoretical model of CAD and effects on currency is explained. We found out that while there are many papers available explaining the $C A D$ and its effects on currency valuation, many of them are empirical in nature and we do not find a good mathematical model that builds the relations between CAD and its effects on currency.

(Gervais, Schembri, \& Suchanek, 2016) have explained the CAD and its effects on the currency exchange rate with empirical analysis. (Forbes, Hjortsoe, \& Nenova, 2016) have done empirical analysis of CAD and their effects on the economy in general. (Shah \& Patnaik, 2007) have done analysis on India's experience with capital flows and how CAD disrupts the smooth flow of currency. (Cerra \& Saxena, 2002) have analysed in detail the currency crisis that occurred in India during the early nineties and the causes of this crisis. (Milesi-Ferrett \& Razin, 1998) have done analysis on Current account reversals and how it leads to currency crisis. (Kenneth A Froot, 1991) have done detailed empirical analysis of exchange rates and how it affects the FDI in to an economy. (Rose \& Wyplosz, 1996) have done a very detailed analysis of how CAD can be contagious and can lead to a vicious cycle of currency fluctuations.

\section{Mathematical Model and Methods}

The Method used in this study is based on statistical significance testing as this method provides a complete basis for quantitative analysis and since this paper deals with CAD which deals with quantitative figures, the authors chose to use the detailed statistical analysis and mathematical regression model to derive the relationship between $C A D$ and its effect on Currency valuation

The model is based on the Supply and demand curves of Dollar with respect to the Indian rupee, where PO and QO denote the price of dollar in Indian Rupees and quantity of US dollars in demand under equilibrium conditions. In this Model, we consider the US dollar supply to be unchanged represented by the supply curve, whereas the demand curve varies with the fluctuations in CAD represented by "Demand Curve -D0" and "Demand Curve - D1" respectively. 
Let's assume that the CAD is in deficit and that requires more quantity of dollars to be procured to meet the import obligations, the new demand curve D1 based on the new CAD meets the supply curve at a new equilibrium point represented by $(P 1, Q 1)$. The difference of the CAD and in-turn the dollar demand can be viewed at the new intercept of the $\mathrm{X}$ - axis made the demand curve D2.

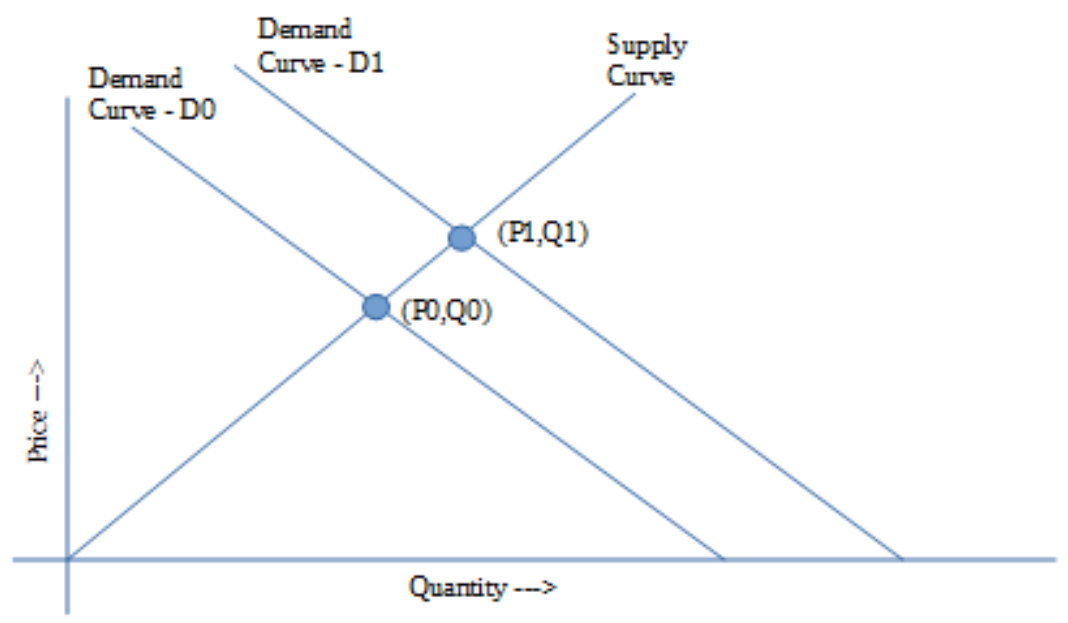

Figure 1. Supply and Demand Curves for Currency

The equations are below:

$$
\begin{aligned}
& P=a 1 . q+b 1----- \text { SupplyCurve }- \text { Equation } 1 \\
& p=a 2 . q+b 2----- \text { DemandCurve }- \text { Equation } 2
\end{aligned}
$$

Solving the above equations for Equilibrium point $(\mathrm{PO}, \mathrm{Q} 0)$ using matrix methodology. 


$$
\begin{gathered}
A X=B--- \text { Equation } 3 \\
{\left[\begin{array}{ll}
1 & -a 1 \\
1 & -a 2
\end{array}\right]\left[\begin{array}{l}
P \\
Q
\end{array}\right]=\left[\begin{array}{l}
b 1 \\
b 2
\end{array}\right]--- \text { Equation } 4} \\
X=\operatorname{Inv}(A) \cdot b--- \text { Equation } 5 \\
\operatorname{Inv}(A)=\frac{1}{\operatorname{Det}(A)}\left[\begin{array}{cc}
-a 2 & a 1 \\
-1 & 1
\end{array}\right]--- \text { Equation } 6
\end{gathered}
$$

Solving the above equations, we get:

$$
\begin{gathered}
P=\frac{a 1 . b 2-a 2 . b 1}{a 1-a 2}-- \text { Equation } 7 \\
Q=\frac{b 2-b 1}{a 1-a 2}--- \text { Equation } 8
\end{gathered}
$$

Now lets consider a condition that CAD changes and it in-turn effects the demand for the US Dollar with respect to Indian Rupee, also for simplicity, let's keep the dollar supply constant without any change as in reality dollar supply is also affected by demand fluctuations. Now, the change in CAD is represented by CAD, which basically is the new demand for US dollars compared to the earlier equilibrium point $(\mathrm{PO}, \mathrm{Q} 0)$.

The new equilibrium point is represented by $(\mathrm{P} 1, \mathrm{Q} 1)$ on the new demand curve Demand- 2 . Utilize equations $7 \& 8$ to calculate the new equilibrium points as follows:

$$
\begin{gathered}
P 1=\frac{a 1(b 2+C A D)-a 2 \cdot b 1}{a 1-a 2}-- \text { Equation } 9 \\
Q 1=\frac{(b 2+C A D)-b 1}{a 1-a 2}-- \text { Equation } 10
\end{gathered}
$$

Reducing the above equation as follows: 
INTERNATIONAL JOURNAL OF ACADEMIC RESEARCH IN BUSINESS AND SOCIAL SCIENCES

Vol. 8, No. 10, Oct. 2018, E-ISSN: 222 2-6990 @ 2018 HRMARS

$$
\begin{gathered}
P 1=\frac{a 1 \cdot b 2-a 2 \cdot b 1}{a 1-a 2}+\frac{a 1 \cdot C A D}{a 1-a 2}--- \text { Equation } 11 \\
P 1=P 0+\frac{a 1 \cdot C A D}{a 1-a 2}-- \text { Equation } 12 \\
Q 1=\frac{b 2-b 1}{a 1-a 2}+\frac{C A D}{a 1-a 2}-- \text { Equation } 13 \\
Q 1=Q 0+\frac{C A D}{a 1-a 2}-- \text { Equation } 14
\end{gathered}
$$

The equations 12 and 14 represent the new equilibrium point (P1,Q1), where $P 1$ is the new price for US dollar quoted in Indian Rupees and Q1 is the new quantity of US dollars demanded.

\section{Empirical Data Analysis and Results India's CAD data and Descriptive statistics}

In this section we will test the model built in our earlier section with statistical data about India's CAD

\begin{tabular}{|c|c|c|c|c|c|c|}
\hline \multicolumn{7}{|c|}{ India's Historical Balance of Payments(US\$ Billion) } \\
\hline Sno & Period & \begin{tabular}{|l|} 
Net Current \\
Account
\end{tabular} & \begin{tabular}{|l|} 
Net Capital \\
Account
\end{tabular} & \begin{tabular}{|l|} 
Errors I \\
Omissions
\end{tabular} & Overall Balance & INR Value \\
\hline 1 & FY1990-1991 & $-\$ 9.68$ & $\$ 7.06$ & $\$ 0.13$ & $-\$ 2.49$ & $₹ 20.00$ \\
\hline 2 & FY1993-1994 & $-\$ 1.16$ & $\$ 9.88$ & $\$ 0.00$ & $\$ 8.72$ & $₹ 35.00$ \\
\hline 3 & FY1994-1995 & $-\$ 3.37$ & $\$ 8.01$ & $\$ 0.00$ & $\$ 4.64$ & $₹ 35.00$ \\
\hline 4 & FY1995-1996 & $-\$ 5.90$ & $\$ 4.08$ & $\$ 0.60$ & $-\$ 1.22$ & $₹ 38.00$ \\
\hline 5 & FY1996-1997 & $-\$ 4.49$ & $\$ 11.88$ & $-\$ 0.59$ & $\$ 6.79$ & $₹ 40.00$ \\
\hline 6 & FY1997-1998 & $-\$ 6.47$ & $\$ 11.92$ & $-\$ 0.94$ & $\$ 4.51$ & $₹ 42.00$ \\
\hline 7 & FY1998-1999 & $-\$ 4.04$ & $\$ 8.57$ & $-\$ 0.31$ & $\$ 4.22$ & $₹ 43.00$ \\
\hline 8 & FY1999-2000 & $-\$ 18.00$ & $\$ 44.39$ & $\$ 1.38$ & $\$ 27.77$ & $₹ 45.00$ \\
\hline 9 & FY2000-2001 & $\$ 6.72$ & $\$ 45.72$ & $\$ 4.15$ & $\$ 56.59$ & $₹ 47.00$ \\
\hline 10 & FY2001-2002 & $\$ 16.43$ & $\$ 41.08$ & $-\$ 0.91$ & $\$ 56.59$ & $₹ 45.00$ \\
\hline 11 & FY2002-2003 & $\$ 30.66$ & $\$ 52.37$ & $-\$ 0.99$ & $\$ 82.04$ & $₹ 43.00$ \\
\hline 12 & FY2003-2004 & $\$ 47.95$ & $\$ 94.58$ & $\$ 1.46$ & $\$ 143.99$ & $₹ 42.00$ \\
\hline 13 & FY2004-2005 & $-\$ 29.50$ & $\$ 143.53$ & $\$ 1.88$ & $\$ 115.91$ & $₹ 42.00$ \\
\hline 14 & FY2005-2006 & $-\$ 9.90$ & $\$ 25.47$ & $-\$ 0.52$ & $\$ 15.05$ & $₹ 39.00$ \\
\hline 15 & FY2006-2007 & $-\$ 9.57$ & $\$ 45.20$ & $\$ 0.97$ & $\$ 36.61$ & F39.00 \\
\hline 16 & FY2007-2008 & $-\$ 17.03$ & $\$ 107.99$ & $\$ 1.21$ & $\$ 92.16$ & $₹ 40.00$ \\
\hline 17 & FY2008-2009 & $-\$ 29.82$ & $\$ 9.15$ & $\$ 0.59$ & $-\$ 20.08$ & $₹ 45.00$ \\
\hline 18 & FY2009-2010 & $-\$ 38.41$ & $\$ 53.60$ & $-\$ 1.75$ & $\$ 13.45$ & $₹ 42.00$ \\
\hline 19 & FY2010-2011 & $-\$ 44.28$ & $\$ 59.75$ & $-\$ 2.42$ & $\$ 13.05$ & $₹ 41.00$ \\
\hline 20 & FY2011-2012 & $-\$ 45.95$ & $\$ 61.99$ & $-\$ 2.99$ & $\$ 13.05$ & $₹ 55.00$ \\
\hline 21 & FY2012-2013 & $-\$ 88.16$ & $\$ 89.30$ & $\$ 2.69$ & $\$ 3.83$ & $₹ 70.00$ \\
\hline 22 & FY2013-2014 & $-\$ 32.36$ & $\$ 48.09$ & $-\$ 0.88$ & $\$ 14.85$ & $₹ 68.00$ \\
\hline 23 & FY2014-2015 & $-\$ 27.94$ & $\$ 89.96$ & $-\$ 0.62$ & $\$ 61.41$ & $₹ 68.00$ \\
\hline 24 & FY2015-2016 & $-\$ 22.15$ & $\$ 41.13$ & $-\$ 1.07$ & $\$ 17.91$ & $₹ 67.00$ \\
\hline 25 & FY2016-2017 & $-\$ 15.30$ & $\$ 36.48$ & $\$ 0.36$ & $\$ 21.55$ & $₹ 64.00$ \\
\hline
\end{tabular}
and subject the data to simple linear Regression analysis to validate the Model. The data used in this section is from Reserve Bank of India (RBI) sources. The last 25 years of data relating to India's CAD, Net Capital account and Overall Balance of Payments data has been presented for analysis.

Figure 2. India's Historical Balance of Payments summary 
INTERNATIONAL JOURNAL OF ACADEMIC RESEARCH IN BUSINESS AND SOCIAL SCIENCES Vol. 8, No. 10, Oct. 2018, E-ISSN: 222 2-6990 @ 2018 HRMARS

\section{Descriptive Statistics}

\begin{tabular}{|l|l|l|l|l|l|}
\hline & $\begin{array}{l}\text { Net Current } \\
\text { Account }\end{array}$ & $\begin{array}{l}\text { Net Capital } \\
\text { Account }\end{array}$ & $\begin{array}{l}\text { Errors I } \\
\text { Omissions }\end{array}$ & Overall Balance & INR Value \\
\hline Mean & $-\$ 14.47$ & $\$ 46.05$ & $\$ 0.06$ & $\$ 31.64$ & $₹ 46.20$ \\
\hline $\begin{array}{l}\text { Standard } \\
\text { Error }\end{array}$ & 5.3190526672 & 7.2730692101 & 0.3128822307 & 8.0643730984 & 2.467117076 \\
\hline Mode & NA & NA & NA & NA & 42 \\
\hline Median & -9.902 & 44.39 & NA & 14.849 & 42 \\
\hline Variance & 707.3080319067 & 1322.43839339 & 2.4473822567 & 1625.8528367433 & 152.1666666667 \\
\hline $\begin{array}{l}\text { Standard } \\
\text { Deviation }\end{array}$ & 26.5952633359 & 36.3653460507 & 1.5644111533 & 40.3218654919 & 12.33558538 \\
\hline Kurtosis & 2.1869709845 & 0.6810981908 & 0.9577450188 & 1.5328627486 & 0.2461743376 \\
\hline Skewness & -0.254967271 & 0.9636918119 & 0.5313953369 & 1.4299294427 & 0.6380799011 \\
\hline Range & $\$ 136.12$ & $\$ 139.45$ & $\$ 7.14$ & $\$ 164.07$ & $₹ 50.00$ \\
\hline Minimum & $-\$ 88.16$ & $\$ 4.08$ & $-\$ 2.99$ & $-\$ 20.08$ & $₹ 20.00$ \\
\hline Maximum & $\$ 47.95$ & $\$ 143.53$ & $\$ 4.15$ & $\$ 143.99$ & $₹ 70.00$ \\
\hline
\end{tabular}

Figure 3. Descriptive Statistics of the Balance of Payments Data

The line charts of CAD and Indian Rupee value is displayed below and we can definitely see the trend where increase in CAD is causing the Indian Rupee value to increase w.r.t to US Dollar.

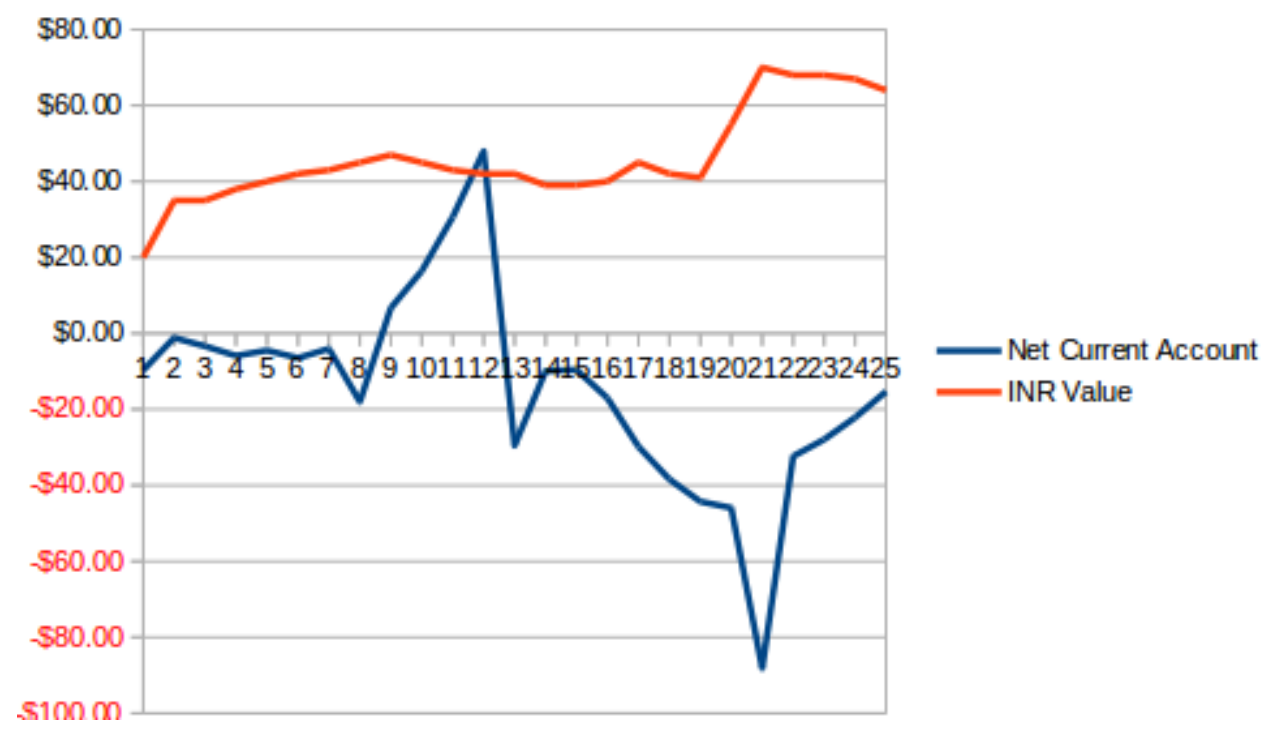

\section{Regression Analysis}

Figure 4. Trend Lines Comparison between CAD and Currency

In this section, we subject the CAD data to Regression analysis and validate the model built in the earlier section. Consider the final equation of the New price of Indian Rupee after changes in CAD represented by Equation 12.

$$
P 1=P 0+\frac{a 1 \cdot C A D}{a 1-a 2}
$$

The above equation can further reduced by re-arranging the constants:

$$
P 1=P 0+K \cdot C A D--- \text { Equation15 }
$$


INTERNATIONAL JOURNAL OF ACADEMIC RESEARCH IN BUSINESS AND SOCIAL SCIENCES

Vol. 8, No. 10, Oct. 2018, E-ISSN: 222 2-6990 @ 2018 HRMARS

$\mathrm{K}$ represents the equation intercept.

Now consider Regression analysis as below:

\begin{tabular}{lr}
\hline \multicolumn{2}{c}{ Regression Statistics } \\
\hline Multiple R & 0.3196099894 \\
R Square & 0.1021505453 \\
Adjusted R Square & 0.0631136125 \\
Standard Error & 10.7418307325 \\
Observations & 25 \\
\hline
\end{tabular}

The R Squared value is low as expected as the Indian Rupee is based many other factors such as the demand and stability of US Dollar, In our study we have kept these things unchanged for simplicity. The Indian Rupee would be relatively stable for minor changes in the CAD, but would rise exponentially rise with increasing CAD as can be seen from the data.

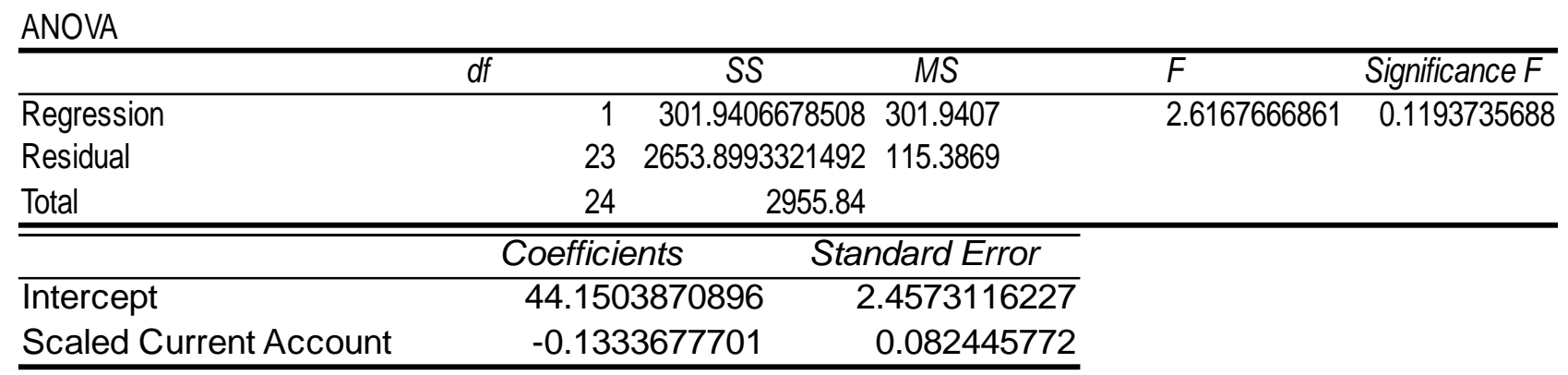

RESIDUAL OUTPUT

\begin{tabular}{rrrr}
\hline Observation & & Predicted INR Value & \multicolumn{1}{c}{ Residuals } \\
\hline 2 & 45.4413871043 & -25.4413871043 \\
3 & 44.3048269674 & -9.3048269674 \\
4 & 44.5997031071 & -9.5997031071 \\
5 & 44.9371235655 & -6.9371235655 \\
6 & 44.7497418485 & -4.7497418485 \\
7 & 44.6889261453 & -1.6889261453 \\
8 & 46.5508735839 & -1.5508735839 \\
9 & 43.2542890422 & 3.7457109578 \\
10 & 41.9596880977 & 7.0403119023 \\
11 & 40.0613312578 & 9.9386687422 \\
12 & 37.755135777 & 5.244864223 \\
13 & 48.0842028369 & -6.0842028369 \\
14 & 45.4709947493 & -4.4709947493 \\
15 & 45.4260498107 & -5.4260498107 \\
16 & 46.4221736857 & -6.4221736857 \\
17 & 48.1270138911 & -3.1270138911 \\
18 & 49.2731765075 & -7.2731765075 \\
19 & 50.056045318 & -9.056045318 \\
20 & 50.2779692875 & 4.7220307125 \\
21 & 55.9084898062 & 4.0915101938 \\
22 & 48.465901395 & 19.534098605 \\
23 & 47.8762824833 & 12.1237175167 \\
24 & 47.1046165654 & 19.8953834346 \\
25 & 46.1903805013 & 17.8096194987 \\
\hline
\end{tabular}


INTERNATIONAL JOURNAL OF ACADEMIC RESEARCH IN BUSINESS AND SOCIAL SCIENCES

Vol. 8, No. 10, Oct. 2018, E-ISSN: 2222-6990 ㄷ 2018 HRMARS

Based on the above data the $\mathrm{K}$ value in equation 15 is -0.1333 and the intercept is 44.15 , which essentially means the the base rate of Indian Rupee is INR 44.15. Thus the model we built in this paper is validated using CAD data.

\section{Implications of the Study}

The short term and long term effects of CAD based on the Mathematical model developed in the earlier sections.

\section{Short Term Effects}

The following are the short term impacts of CAD:

- A high negative CAD puts pressure of the domestic currency and leads to devaluation of the currency, in-turn making imports more costlier

- The foreign investors pull out money from the country when domestic currency loses its value, this sets a chain reaction of money flowing out of the country and further eroding the value of the currency

- The government has to finance the CAD through external borrowing and make interest payments leading to money getting sucked out of the domestic economy and in-turn leading to higher interest rates

- Higher interest rates increases the cost of borrowing money and slows down the domestic economy

- Slow growing economy leads to higher unemployment rate and leads to social unrest in the country

\section{Long Term Effects}

The following are the long term impacts of CAD are:

- In a country like India's where FDI is an important component, sustained CAD leads to loss of confidence with Foreign Investors

- Sustained high levels of CAD will lead to Hyper Inflation in the domestic economy

- High Interest rates for long periods of time will lead to economic contraction

- Economic contraction will lead to unemployment and chaos in the society

- Commodity prices will be out of reach of common man and will lead to famine in the country

- Unemployment for a long time will lead to illiteracy and loss of knowledge

\section{Conclusions}

In this paper, we have a made an attempt to model the CAD and its effects on the currency valuation. The mathematical model developed here has taken liberty to make many assumptions to make the model simple and easy to understand even for novice readers. We subjected the Model to Empirical analysis using CAD from Reserve Bank of India (RBI) sources for the last 25 years and validate the model using regression analysis. We infer that the effects of CAD deficit have a very wide reaching harmful consequences on the economy and the policy makers should keep in mind that "Living within 
INTERNATIONAL JOURNAL OF ACADEMIC RESEARCH IN BUSINESS AND SOCIAL SCIENCES

Vol. 8, No. 10, Oct. 2018, E-ISSN: $2222-6990$ C 2018 HRMARS

means" should be adopted by the political class and reduce dependence on the imports as far as possible.

\section{References}

Cerra, V., \& Saxena, S. C. (2002). What Caused the 1991 Currency Crisis in India? IMF Staff Papers, 49(3), 395-425. https://doi.org/10.2307/3872503

Forbes, K., Hjortsoe, I., \& Nenova, T. (2016). Current Account Deficits During Heightened Risk : NBER Working Paper Series, 22741.

Gervais, O., Schembri, L., \& Suchanek, L. (2016). Current account dynamics, real exchange rate adjustment, and the exchange rate regime in emerging-market economies. Journal of Development Economics, 119(C), 86-99. https://doi.org/10.1016/j.jdeveco.2015.09

Kenneth A Froot, J. C. S. (1991). Exchange Rates and Foreign Direct Investment: An Imperfect Capital Markets Approach.

Milesi-Ferrett, G. M., \& Razin, A. (1998). Current Account Reversals and Currency Crises: Empirical Regularities. https://doi.org/10.3386/w6620

Rose, A. K., \& Wyplosz, C. (1996). No Title.

Shah, A., \& Patnaik, I. (2007). India's experience with capital flows: The elusive quest for a sustainable current account deficit. Capital controls and capital flows in emerging. https://doi.org/10.3386/w11387 